\title{
A BRIDGE TO THE FUTURE: VOLCANIC ISLANDS AS NATURAL LABORATORIES
}

\author{
Sara González-Delgado* \\ Universidad de La Laguna
}

\begin{abstract}
We know that oceanic islands are perfect as model system to understand ecological, evolutionary and conservation process. In the present work, it is intended to go farther and emphasize the importance of volcanic island as natural laboratory to study the ocean acidification (OA). Under certain conditions, the volcanic activity creates a vent system in islands which emitting gases rich in $\mathrm{CO}_{2}$. Therefore, it creates a future scenario where chemical characteristic expected will appear, such as lower $\mathrm{pH}$ and lower concentrations of aragonite and calcite. Here, I present 22 vent systems located on volcanic islands distributed all over the world. Each of them has been studied to discover the negative impact of OA in marine organisms. Overcoming in vitro experiments, the investigation of vent has offered the possibilities of understanding the future. To comprehend how an entire community is adapted and developed with different interactions of species and ecological functions under continuous acidity. I am facing another proof that the islands are unique places that help us to obtain new solutions to maintain and preserve life on our planet.
\end{abstract}

KEYwORDs: $\mathrm{CO}_{2}$ vent, ocean acidification, oceanic island, climate change.

\section{UN PUENTE HACIA EL FUTURO: ISLAS VOLCÁNICAS COMO LABORATORIOS NATURALES}

\section{RESUMEN}

Las islas oceánicas son modelos perfectos para entender los procesos ecológicos, evolutivos y de conservación. En este trabajo, se pretende dar un paso más allá y enfatizar en su importancia como laboratorio natural para la acidificación del océano (AO). Bajo determinadas condiciones, la actividad volcánica de una isla genera emisiones de $\mathrm{CO}_{2}$ que afecta al agua circundante. En consecuencia, se crea un escenario con las características químicas esperadas en los océanos del futuro, como niveles de $\mathrm{pH}$ y concentraciones de carbonato cálcico inferiores. Se presentan 22 surgencias de $\mathrm{CO}_{2}$ ubicadas en islas volcánicas de todo el mundo. En cada una de ellas se han realizado estudios para conocer el impacto negativo de la $\mathrm{AO}$ en los organismos marinos. Superando a la experimentación, estos estudios ha ofrecido la posibilidad de comprender mejor cómo se adapta y desarrolla comunidades entera con diferentes interacciones de especies y funciones ecológicas bajo una continua acidificación. Estamos ante otra evidencia que apoya que las islas volcánicas son lugares únicos que nos ayudan a obtener nuevas soluciones para mantener y preservar la vida en nuestro planeta. Palabras Clave: afloramiento de $\mathrm{CO}_{2}$, acidificación, islas oceánicas, cambio climático. 


\section{INTRODUCTION}

It is already universal knowledge, that volcanic islands are not only pieces of land in the middle of the ocean, but also greats natural laboratories. An island is volcanic when it formed through the accumulation of submarine magma, which never connected with continents and for that reason, are commonly called Oceanic islands. Therefore, islands are isolated systems that are found in all geographical latitudes, have different ages and contrasting sizes. All of these makes islands to contribute five times more than the continents to the global biodiversity (Whittaker et al. 2007). These characteristics make that experts from all over the world have used them as model systems to study many disciplines such as ecology, evolution, conservation and biogeographical phenomena (Whittaker et al. 2017). They are considered little representations of whole continents at a micro-scale, with high topographic diversity, contrasting climates and as consequence, with heterogeneous habitats where endemic flora and fauna live (Kueffer and Kinney, 2017). Furthermore, islands are living museums of natural heritage, hotspots of cultural, biological and geophysical riches due to their extraordinary environmental dynamic (Kueffer and Kinney, 2017).

Nonetheless, at the same time, what makes islands exceptional also makes them very vulnerable to climate change (CC). For example, the presence of low population sizes, high limited resources in small areas, special and variable environmental conditions or the unique biota that is adapted to these habitats, generate greater possibilities of extinction to small changes (Wood et al. 2017). Since the industrial revolution, the use of fossil fuels has been produced an excess of carbon dioxide $\left(\mathrm{CO}_{2}\right)$ in the atmosphere and the oceans (Sabine et al. 2004). Both accumulations are creating two main consequence, the global warming $(\mathrm{GW})$ and the ocean acidification (OA) respectively, that will affect severely marine life. The increase of seawater temperature and the drop of $\mathrm{pH}$ is probably two of the most evident effects of climate change (CC) right now (IPCC, 2014), and the volcanic islands plays an important role in their investigation. In the present work, I wanted to emphasize in the importance of volcanic island as natural laboratory to study climate change effect in marine live and in particular the ocean acidification.

\section{VOLCANIC ISLAND AND CLIMATE CHANGE}

Volcanic islands are characterized by a high ratio of coastline being the location of world marine ecosystem, becoming in the places with most ecological influence on oceans (Kueffer and Kinney, 2017). Consequently, climate change

* Departamento de Biología Animal, Edafología y Geología, Facultad de Ciencias (Sección Biología), Universidad de La Laguna, Tenerife, Canary Islands, Spain. Corresponding author: saglezdel@gmail.com. 
poses a great threat to them. For example, the increase of temperature is altering the normal limits of distribution of many organisms causing the tropicalization process (Harley et al. 2006). The study of this phenomenon is easier using subtropical island such as the Canary Islands. In this subtropical volcanic archipelago the native tropical species and the non-native species that arrive, develop and establish quickly (e.g. fishes, Brito, 2005). Meanwhile, species with temperate affinities are being progressively reduced (e.g. algae, Álvarez-Canali et al. 2019). On the other hand, the acidification is not so well known because the most visible effects are expected in the near future (IPCC, 2014). Acidification occurs when $\mathrm{CO}_{2}$ is dissolved in seawater generating an imbalance in water chemistry. The future increase of this gas in oceans will have serious consequences for many marine organisms owing to the drop of $\mathrm{pH}$ and aragonite and calcite saturation state in seawater (Orr et al. 2005). This disequilibrium will cause a negative effect in species with skeleton or protective shell such as corals, crustaceans, molluscs and single-celled organisms, those with endoskeletons, such as echinoderms (Kroeker et al. 2010) or algae species with calcified bodies (Koch et al. 2013). For this reason, several authors have been trying to understand the future affected by OA, but it is become a great challenge due to their complexity. Although the laboratory experiments have helped to predict the future, there are still great gaps of information like the large temporal or spatial effects or the whole populations or communities change. Here, it is where the volcanic islands enter, being able by their nature to become an incredible tool to study acidification (Hernández et al. 2016; González-Delgado and Hernández, 2018).

\section{VOLCANIC ISLAND AS NATURAL LABORATORY TO STUDY OA}

Under certain conditions, the volcanic activity of an island is capable of generate a natural phenomenon near the coast that is called $\mathrm{CO}_{2}$ vent systems. These natural systems are characterized by emitting gases of volcanic origin, very rich in $\mathrm{CO}_{2}$. These generate an imbalance in the carbon system of seawater, increasing the concentration of bicarbonate $\left(\mathrm{HCO}_{3}{ }^{-}\right)$and hydrogen ions $\left(\mathrm{H}^{+}\right)$, causing acidification of the surrounding water.

Therefore, $\mathrm{CO}_{2}$ vent systems creates an analogue scenario of the future where chemical characteristic expected by CC specialists will appear in the ocean, such as lower $\mathrm{pH}$ and lower concentrations of aragonite and calcite (González-Delgado and Hernández, 2018).

Until today, there are 22 vent shallow systems located on volcanic islands that are distributed all over the world in 14 areas (Fig. 1). Each of them has been studied with the same purpose, to discover the negative impact of OA in local marine organisms. These places have relations with the area where volcanos are still active as island arcs, mid-oceanic ridges and intra-plate magmatism, which are distributed in all oceans (Tarasov et al. 2005). Thanks to that we know how will evolve different marine islander ecosystem from temperate, tropical and subtropical regions in the future world affected by acidification. 
Maybe the most direct negative impacts of OA on island ecosystem would be in coral reefs. Tropical vent systems like Papua New Guinea islands have offered the unique opportunity to observe the serious effect on corals both in the animal already formed and in the process of their larval settlement and growth (Fabricius et al. 2011; 2017). Furthermore, coral reef are the structuring organisms and the study of these vents have allowed us to observe indirect consequences, such as the negative effect on invertebrates associated with them (Fabricius et al. 2014). Hence, these studies emphasize that in the near future, we will lose the most important marine habitat of our planet and the important services that they provide (Enochs et al. 2015; Hall-Spencer and Harvey, 2019).

Subtropical marine communities also have an important role on in this research field. The boundaries between the tropical and temperate ecosystems are the last refuge of many organisms that have their distribution limit in these islands. Consequently, these species are already fighting for their survival in these habitats, generating a diversity vulnerable to any alteration (Kuffer and Kinney, 2017). The acidified natural subtropical systems have shown us that when acidification is added on this environment, we have a complete loss of functional biodiversity in the ecosystem (González-Delgado et al., in press). The calcifying organisms disappear and with them the source of carbonate, the living habitats (corals, sponges, calcareous algae, etc.) and the main herbivores like mollusc or sea urchins (Pérez, 2017; Agostini et al. 2018; Viotti et al. 2019; González-Delgado et al. in prep). The most impressive change is in the ecosystems itself. Due to the extra $\mathrm{C}$ in seawater, the common structuring algae that usually dominated vanish and appears other with less functionality (González-Delgado et al. in prep).

Respectively, Mediterranean temperate islands will change in a negative way too, losing species diversity that's leads also to an imminent loss of ecological functions (Foo et al. 2018; Teixidó et al. 2018). The island of Ischia (Italy) is where the first work about acidified systems appears as natural laboratory (Hall-Spencer $e t$ al. 2008), and the most studied vent system in the world (Foo et al. 2018). For this reason, the most recent works in the Ischia systems demonstrate the importance of vent systems to perform new studies of OA on evolutionary adaptations and longterm physiological effects (Olivé et al. 2017; Kumar et al. 2017; Porzio et al. 2017; Migliaccio et al. 2019).

Volcanic island with acidify systems demonstrate that OA is a great threat by itself, and together with the other CC stressors, will cause a big disequilibrium in the island ecosystem, a damage in ecological services and in their habitat complexity, that we will pay with the loss of marine goods and services available to society (HallSpencer and Harvey, 2019).

This note is facing more evidence of the great value of a volcanic island. The presence of vent systems not only confronts us with an imminent future, but it is also giving us the opportunity to face the changes. This is because, beyond all studies on the effects of ocean acidification, islands with acidify systems have a natural refuge, becoming a great tool to environmental conservation. In these places, the species live under different variations of acidification, adapting to the natural changes of water chemistry, providing them with the necessary characteristics to survive in 
the future world (e.g. calcifying algae: Linares et al. 2015; polychaetes: Calosi et al. 2013(a); sea urchins (Calosi et al. 2013(b), Epherra et al. in prep).

\section{CONCLUSIONS}

Overcoming in vitro experiments, the investigation of natural acidify systems, which have been carried out on islands, offer a bridge to understand the future; allowing us to comprehend how an entire community will be adapted and developed with different interactions of species, physiological processes and ecological functions under ocean acidification. Here, there is another proof of what had already been confirmed; the islands are unique places that help us move towards sustainable development, winning new solutions to maintain and preserve life on our planet.

\section{ACKNOWLEDGMENT}

Thanks to my dear PhD advisor Super Intendente José Carlos Hernández and to his wonderful colleague Carlos Sangil for his review on the first version of this paper.

\section{AUTHORS CONTRIBUTION}

The author is the only responsible for the whole paper.

RECIBIDo: julio de 2019; ACEPTADo: enero de 2020 


\section{REFERENCES}

Agostini, S., Wada, S., Kon, K., Omori, A., Kohtsuka, H., Fujimura, H., et al. 2015. Geochemistry of two shallow $\mathrm{CO}_{2}$ seeps in Shikine Island (Japan) and their potential for ocean acidification research. Reg. Stud. Mar. Sci. 2, 45-53.

Álvarez-Canali, D., Sangil, C., Reyes, J. \& Sansón, M. 2019. Local variations in environmental parameters govern 50 years of the decline of Fucus guiryi populations in the Canary Islands (eastern Atlantic). J. Sea Res. p. 101823.

Arnold, T., Mealey, C., Leahey, H., Miller, A.W., Hall-Spencer, J.M., Milazzo, M. \& Maers, K. 2012. Ocean acidification and the loss of phenolic substances in marine plants. PLoS One 7 (4), e35107.

Bray, L., Pancucci-Papadopoulou, M.A. \& Hall-Spencer, J.M. 2014. Sea urchin response to rising $\mathrm{pCO}_{2}$ shows ocean acidification may fundamentally alter the chemistry of marine skeletons. Mediterr. Mar. Sci. 15 (3), 510-519.

Brinkman, T.J. \& SMith, A.M. 2015. Effect of climate change on crustose coralline algae at a temperate vent site, White Island, New Zealand. Mar. Freshw. Res. 66 (4), 360-370.

Brito, A., Falcón J.M. \& Herrera, R. 2005. Sobre la tropicalización reciente de la ictiofauna litoral de las islas Canarias y su relación con lo cambios ambientales y actividades antrópicas. Vieraea 33, 515-525.

Calosi, P., Rastrick, S.P.S., Lombardi, C., de Guzman, H.J., Davidson, L., Jahnke, M., et al. 2013a. Adaptation and acclimatization to ocean acidification in marine ectotherms: an in situ transplant experiment with polychaetes at a shallow CO2 vent system. Philos. Trans. R. Soc. B 368, 20120444.

Calosi, P., Rastrick, S.P.S., Graziano, M., Thomas, S.C., Baggini, C., Carter, H.A., HallSpencer, J.M., Milazzo, M. \& Spicer, J.I. 2013b. Distribution of sea urchins living nearshallow water $\mathrm{CO} 2$ vents is dependent upon species acid-base and ion-regulatory abilities. Mar. Pollut. Bull. 73 (2), 470-484. Epherra et al. in press

Enochs, I.C., Manzello, D.P., Donham, E.M., Kolodziej, G., Okano, R., Johnston, L., et al. 2015. Shift from coral to macroalgae dominance on a volcanically acidified reef. Nat. Clim. Chang. 5 (12), 1083-1088.

Fabricius, K.E., Langdon, C., Uthicke, S., Humphrey, C., Noonan, S., De'ath, G., et al. 2011. Losers and winners in coral reefs acclimatized to elevated carbon dioxide concentrations. Nat. Clim. Chang. 1 (3), 165-169.

Fabricius, K.E., De’ath, G., Noonan, S. \& Uthicke, S. 2014. Ecological effects of ocean acidification and habitat complexity on reef-associated macroinvertebrate communities. Proc. R. Soc. B 281 (1775), 20132479.

Fabricius, K.E., Noonan, S.H., Abrego, D., Harrington, L. \& Déath, G, 2017. Low recruitment due to altered settlement substrata as primary constraint for coral communities under ocean acidification. Proc. R. Soc. B 284 (1862), 20171536.

Foo, S.A., Byrne, M., Ricevuto, E., \& Gambi, M.C. 2018. The carbon dioxide vents of Ischia, Italy, a natural system to assess impacts of ocean acidification on marine ecosystems: an overview of research and comparisons with other vent systems. Oceanogr. Mar. Biol. Annu. Rev., 56, 237-310. 
GonzÁlez-Delgado, S. \& Hernández, J.C. 2019. The importance of natural acidfied systems in the study of ocean acidification: what have we learned? Chapter 2. Advances in Marine Biology, 82. 57-99 pp.

Hall-Spencer, J.M., \& Harvey, B.P. 2019. Ocean acidification impacts on coastal ecosystem services due to habitat degradation. Emerg. Top. Lif. Sci., 3(2), 197-206.

Hall-Spencer, J.M., Rodolfo-Metalpa, R., Martin, S., Ransome, E., Fine, M., Turner, S.M., et al. 2008. Volcanic carbon dioxide vents show ecosystem effects of ocean acidification. Nature 454 (7200), 96-99.

Harley, C.D.G., Hughes, A. R., Hultgren, K.M., Miner, B.G., Sorte, C.J.B., Thornber, et al. 2006. The impacts of climate change in coastal marine systems. Ecol. Lett. 9, 228-241.

Hernández, C.A., Sangil, C., Hernández, J.C. 2016. A new $\mathrm{CO}_{2}$ vent for the study of ocean acidification in the Atlantic. Mar. Pollut. Bull. 109 (1), 419-426.

Inoue, S., Kayanne, H., Yamamoto, S. \& Kurihara, H. 2013. Spatial community shift from hard to soft corals in acidified water. Nat. Clim. Chang. 3 (7), 683-687.

IPCC, 2014. In: Core Writing Team, Pachauri, R.K., Meyer, L.A. (eds.), Climate Change 2014: Synthesis Report. Contribution of Working Groups I, II and III to the Fifth Assessment Report of the Intergovernmental Panel on Climate Change, p. 151. Geneva (Switzerland).

Januar, H.I., Zamani, N.P., Soedarma, D. \& Chasanah, E. 2016. Changes in soft coral Sarcophyton sp. abundance and cytotoxicity at volcanic $\mathrm{CO}_{2}$ seeps in Indonesia. AIMS Environ. Sci. 3 (2), 239-248.

Johnson, V.R., Russell, B.D., Fabricius, K.E., Brownlee, C. \& Hall-Spencer, J.M. 2012. Temperate and tropical brown macroalgae thrive, despite decalcification, along natural $\mathrm{CO}_{2}$ gradients. Glob. Chang. Biol. 18 (9), 2792-2803.

Косн, M., Bowes, G., Ross, C. \& Zhang, X.H., 2013. Climate change and ocean acidification effects on seagrasses and marine macroalgae. Glob. Chang. Biol. 19, 103-132. https://doi. org/10.1111/j.1365-2486.2012.02791.x.

Kroeker, K.J., Kordas, R.L., Crim, R.N. \& Singh, G.G. 2010. Meta-analysis reveals negative yet variable effects of ocean acidification on marine organisms. Ecol. Lett. 13, 1419-1434.

Kueffer, C., \& Kinney, K., 2017. What is the importance of islands to environmental conservation? Environ. Conserv., 44(4), 311-322. doi: 10.1017/S0376892917000479.

Kumar, A., Castellano, I., Patti, F.P., Delledonne, M., Abdelgawad, H., Beemster, G.T., et al. 2017. Molecular response of Sargassum vulgare to acidification at volcanic $\mathrm{CO}_{2}$ vents: insights from de novo transcriptomic analysis. Mol. Ecol. 26 (8), 2276-2290.

Linares C., Vidal, M., Canals, M., Kersting, D.K., Amblas, D., Aspillaga, E. et al. 2015. Persistent natural acidification drives major distribution shifts in marine benthic ecosystems. Proc. R. Soc. B Biol. Sci., 282, 20150587 https://doi.org/10.1098/rspb.2015.0587.

Migliaccio, O., Pinsino, A., Maffioli, E., Smith, A.M., Agnisola, C., Matranga, V., et al. 2019. Living in future ocean acidification, physiological adaptive responses of the immune system of sea urchins resident at a $\mathrm{CO}_{2}$ vent system. Science of The Total Environment, 672, 938-950.

OA-ICC-Ocean Acidification International Coordination Centre (2018). Available from: URL: https://news-oceanacidification-icc.org/2018/05/09/call-for-applications-2018-galapagosocean-acidification-school/ (searched on 12 July 2018). 
Olivé, I., Silva, J., Lauritano, C., Costa, M.M., Ruocco, M., Procaccini, G., Santos, R. 2017. Linking gene expression to productivity to unravel long-and short-term responses of seagrasses exposed to $\mathrm{CO}_{2}$ in volcanic vents. Sci. Rep. 7, 42278.

Orr, J.C., Fabry, V.J., Aumont, O., Bopp, L., Doney, S.C., Feely, R.A., et al. 2005. Antrhopogenic ocean acidification over twenty-first century and its impact on calcifying organisms. Nature 437, 681-686.

PÉrez, C., 2017. Effects of a Natural $\mathrm{CO}_{2}$ Gradient on Benthic Coastal Populations. Degree Project, University of La Laguna. http://riull.ull.es/xmlui/handle/915/6758.

Porzio, L., Buia, M.C., Lorenti, M., De Maio, A., Arena, C., 2017. Physiological responses of a population of Sargassum vulgare (Phaeophyceae) to high $\mathrm{pCO}_{2} /$ low $\mathrm{pH}$ : implications for its long-term distribution. Sci. Total Environ. 576, 917-925.

Sabine, C.L., Feely, R.A., Gruber, N., Key, R.M., Lee, K., Bullister, J.L., et al. 2004. The oceanic sink for anthropogenic $\mathrm{CO}_{2}$. Science 305, 367-371.

Tarasov, V.G., Gebruk, A.V., Mironov, A.N., Moskalev, L.I., 2005. Deep-sea and shallow water hydrothermal vent communities: two different phenomena? Chem. Geol. 224 (1-3), 5-39.

Whittaker, R.J. \& Fernández-Palacios, J.M. 2007. Island Biogeography: Ecology, Evolution, and Conservation. Oxford Univ. Press, Oxford, ed. 2.

Whittaker, R.J., Fernández-Palacios, J.M., Matthews, T.J., Borregaard, M.K., \& TRIANTIS, K.A. 2017. Island biogeography: Taking the long view of nature's laboratories. Science, 357(6354), eaam8326.

Wood, J.R., Alcover, J.A., Blackburn, T.M., Bover, P., Duncan, R.P., Hume, J.P. et al. 2017. Island extinctions: processes, patterns, and potential for ecosystem restoration. Environ. Conserve., 44(4), 348-358. 


\section{CAPTION}

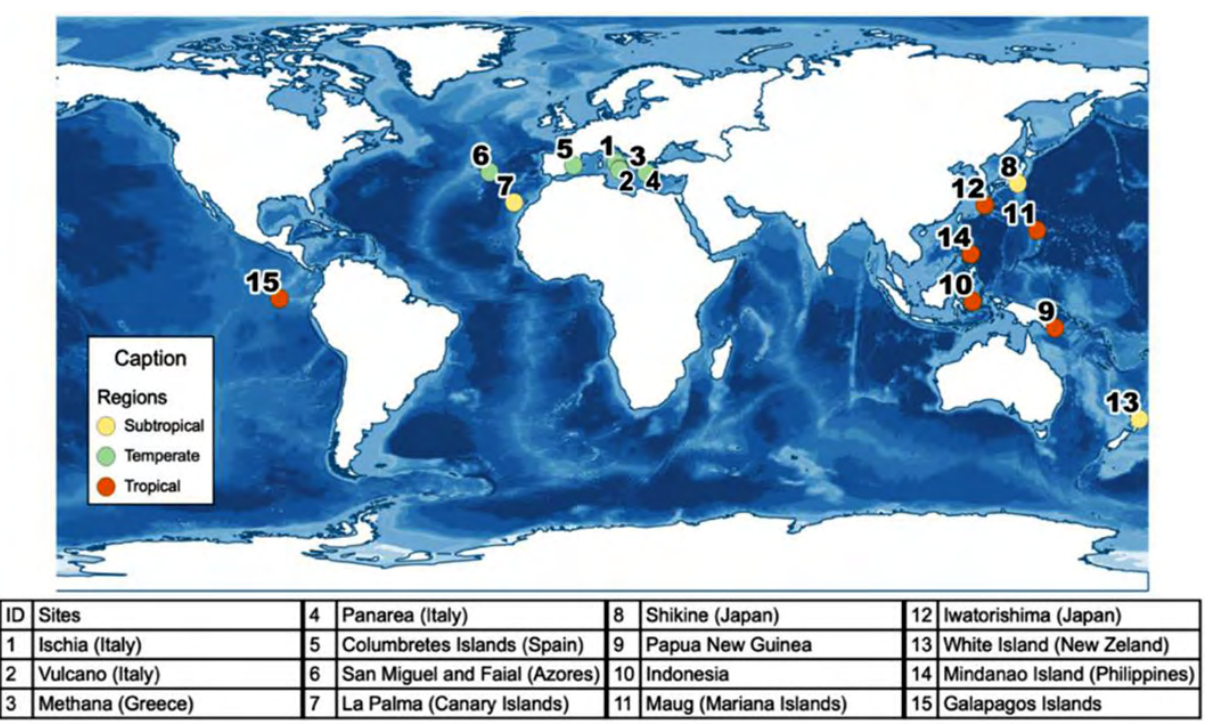

Fig. 1. Location of $\mathrm{CO}_{2}$ vent shallow systems on volcanic islands around the world.

Colours: green: Temperate; orange: tropical; yellow: subtropical ecosystems.

Sources: (1) Hall-spencer et al. 2008; (2) Johnson et al. 2011; (3) Bray et al. 2014; (4) Tassi et al. 2009; (5) Linares et al. 2015; (6) Campoy, 2015; (7) Hernández et al. 2016; (8) Agostini et al. 2015; (9) Fabricius et al. 2011; (10) Januar et al. 2016; (11) Enochs et al. 2015; (12) Inoue et al. 2013; (13) Brinkman., Smith, 2015; (14) Mainit, the Philippines (Dr. Michael Roleda, personal communication); (15) the Galapagos Islands, Ecuador (OA-ICC, 2018). 